Article

\title{
n-6 Linoleic Acid Induces Epigenetics Alterations Associated with Colonic Inflammation and Cancer
}

\author{
Donato F. Romagnolo ${ }^{1,2, *}$, Micah G. Donovan ${ }^{3}$, Tom C. Doetschman ${ }^{4}$ and Ornella I. Selmin ${ }^{1,2}$ \\ 1 The University of Arizona Cancer Center, Tucson, AZ 85724, USA; selmin@email.arizona.edu \\ 2 Department of Nutritional Sciences, University of Arizona, Tucson, AZ 85721, USA \\ 3 Interdisciplinary Cancer Biology Graduate Program, University of Arizona, Tucson, AZ 85724, USA; \\ mdono123@email.arizona.edu \\ 4 Department of Cellular \& Molecular Medicine, University of Arizona, Tucson, AZ 85724, USA; \\ tdoetsch@email.arizona.edu \\ * Correspondence: donato@u.arizona.edu; Tel.: +1-520-626-9108
}

Received: 2 December 2018; Accepted: 10 January 2019; Published: 15 January 2019

\begin{abstract}
The farnesoid-X-receptor (FXR) protects against inflammation and cancer of the colon through maintenance of intestinal bile acid (BA) homeostasis. Conversely, higher levels of BA and cyclooxygenase-2 (COX-2) are risk factors for inflammation and cancer of the colon. In the United States, $n-6$ linoleic acid (LA) is the most commonly used dietary vegetable fat. Metabolism of $n-6$ fatty acids has been linked to a higher risk of intestinal cancer. The objectives of this study were to investigate in colonic mucosa the effects of a high-fat diet rich in LA (n-6HFD) on CpG methylation of $F x r$ and prostaglandin-endoperoxide synthase-2 (Ptsg-2) genes, and the impact on the expression of tumor suppressor adenomatous polyposis Coli $(A p c)$ and proliferative cyclin D1 (Ccnd1) genes. Weaned C57BL/6J male mice were fed for 6 weeks either an $n$-6HFD containing $44 \%$ energy $(44 \% \mathrm{E})$ from $22 \%$ safflower oil (SO, $76 \%$ LA by weight) or a $13 \%$ energy $(13 \% \mathrm{E})$ control diet (Control) from SO ( $5 \%$ by weight). Mice fed the $n$-6HFD had reduced (60\%) Fxr promoter CpG methylation and increased ( $\sim 50 \%)$ Fxr mRNA. The expression of FXR-target ileal bile acid-binding protein $(I b a b p)$, small heterodimer protein $(S h p)$, and anti-inflammatory peroxisome proliferator-activated- $\gamma 1$ genes was increased. The $n$-6HFD reduced Ptgs-2 CpG methylation, increased the expression of Cox-2, and increased Apc CpG methylation in colonic mucosa. Accordingly, reduced expression of $A p c$ was coupled to accumulation of c-JUN and Ccnd1, respectively cofactor and gene targets for the $\beta$-catenin/Wnt signaling pathway. Finally, the $n$-6HFD reduced the expression of histone deacetylase- 1 while favoring the accumulation of acetylated histone 3 . We conclude that an $n-6 \mathrm{HFD}$ epigenetically modifies $F x r$, leading to the activation of downstream factors that participate in BA homeostasis. However, epigenetic activation of Ptsg-2 coupled with silencing of Apc and accumulation of C-JUN and Ccnd1 may increase the risk of inflammation and cancer of the colon.
\end{abstract}

Keywords: $n-6$ linoleic acid; high-fat diet (HFD); bile acids; epigenetics; farnesoid-X-receptor (FXR); cyclooxygenase-2 (COX-2); Apc; colon cancer

\section{Introduction}

A diet high in $n-6$ fatty acids ( $n-6 \mathrm{HFD}$ ) is a recognized risk factor for inflammatory bowel diseases (IBDs) [1,2]. Individuals with diets high in linoleic acid (LA), an $n-6$ fatty acid found predominantly in plant oils (e.g., soybean, corn, safflower), are at increased risk for one common form of IBD, ulcerative colitis [3,4]. In animal studies, the feeding of a vegetable oil (corn oil) rich in LA increases cell proliferation in the colon $[5,6]$. An $n$-6HFD induces the biliary excretion of bile acids (BA), increases fecal levels of the secondary BA deoxycholic acid (DCA), and chemically induced colon cancer 
incidence in rodent models [7]. A causative relationship exists between colon cancer development and a high concentration of rectal BA in preclinical models [8] and human patients [9-12]. Because colon rectal cancer $(C R C)$ is a leading cause of death and its incidence in early onset patients $(<55$ years of age) is on the rise [13], there is great interest in clarifying whether or not intake of an $n$-6HFD increases the risk of CRC through epigenetic mechanisms [14-16].

The farnesoid-X-receptor (FXR) coordinates the expression of genes encoding for enzymes involved in BA homeostasis through the enterohepatic circulation. These include ileal bile acid-binding protein (IBABP) and small heterodimer protein (SHP). In the intestine, SHP lowers the expression of the sodium-dependent bile acid transporter, whereas IBABP coordinates the transcellular movement of BA to the basolateral membrane [17]. In humans, the loss of FXR expression is noted during the transition from late stage colon adenoma to carcinoma [18], and correlates with a higher tumor grade and a poor clinical pathological response [19]. In rodent models, overexpression of Fxr ameliorates tumor growth [20], whereas the genetic deletion of Fxr augments chemically induced colon tumorigenesis [21]. On the other hand, cyclooxygenase-2 (COX-2) overexpression is linked to increased production from arachidonic acid (AA) of prostaglandin E2 (PGE2), which induces cell proliferation [22] and development of CRC [23]. The increased expression of COX-2 and nuclear translocation of $\beta$-catenin are related to a loss of expression of the adenomatous polyposis Coli $(A p c)$ gene and intestinal tumorigenesis [24]. Therefore, dietary factors that alter the relative balance between tumor protective (FXR, Apc) and promoting (COX-2) factors may disrupt homeostasis and contribute to intestinal inflammation and cancer. In this study, we investigated in a mouse model the effects of an $n$-6HFD rich in LA on CpG methylation of Fxr, prostaglandin-endoperoxide synthase-2 (Ptsg-2), and $A p c$ genes, and the expression of factors involved in BA homeostasis (Ibabp and Shp), proliferation (Ccnd1), and oncogenic transformation (c-JUN). Our findings provide new mechanistic insights into the role of an $n-6 H F D$ as a risk factor for CRC through epigenetic activation of Ptsg- 2 and silencing of $A p c$.

\section{Materials and Methods}

\subsection{Animal Models}

Weaned C57/BL6 male mice were purchased from Jackson Laboratories (Bar Harbor, ME, USA) and assigned to a control diet containing 13\% energy (13\%E, 5\% by weight safflower oil (SO), 76\% LA) or an $n$-6HFD containing $44 \%$ energy (44\%E, $22 \%$ by weight SO) (Harlan Laboratories, Madison, WI, USA) for 6 weeks (Table 1). Animals were allowed chow and water ad libitum, and their weight was recorded twice a week. At the end of the experimental periods, colonic tissue was collected as described previously [25]. Briefly, the large intestine was cut open longitudinally and rinsed with ice-cold phosphate-buffered saline (PBS). The proximal colonic mucosa was scraped and cells separated by centrifugation. All animal procedures were approved by the Institutional Animal Care and Use Committee (IACUC) program of The University of Arizona. 
Table 1. Diet composition ${ }^{\mathrm{a}}$.

\begin{tabular}{|c|c|c|c|c|}
\hline $\begin{array}{c}\text { Diet } \\
\text { Formula }\end{array}$ & \multicolumn{2}{|c|}{$\begin{array}{c}\text { Control } \\
\text { (g/Kg) }\end{array}$} & \multicolumn{2}{|c|}{$\begin{array}{c}n-6 H F D \\
(\mathrm{~g} / \mathrm{Kg})\end{array}$} \\
\hline Casein & \multicolumn{2}{|c|}{200.0} & \multicolumn{2}{|c|}{240.0} \\
\hline L-Cystine & \multicolumn{2}{|c|}{3.0} & \multicolumn{2}{|c|}{3.6} \\
\hline Corn Starch & \multicolumn{2}{|c|}{397.5} & \multicolumn{2}{|c|}{199.4} \\
\hline Maltodextrin & \multicolumn{2}{|c|}{132.0} & \multicolumn{2}{|c|}{150.0} \\
\hline Sucrose & \multicolumn{2}{|c|}{120.0} & \multicolumn{2}{|c|}{80.0} \\
\hline Safflower Oil & \multicolumn{2}{|c|}{50.0} & \multicolumn{2}{|c|}{220.0} \\
\hline Cellulose & \multicolumn{2}{|c|}{50.0} & \multicolumn{2}{|c|}{50.0} \\
\hline Mineral Mix, AIN-93G-MX(94046) & \multicolumn{2}{|c|}{35.0} & \multicolumn{2}{|c|}{42.0} \\
\hline Mineral Mix, AIN-93-VX(94047) & \multicolumn{2}{|c|}{10.0} & \multicolumn{2}{|c|}{12.0} \\
\hline Choline Bitartrate & \multicolumn{2}{|c|}{2.5} & \multicolumn{2}{|c|}{3.0} \\
\hline TBHQ, Antioxidant & \multicolumn{2}{|c|}{0.01} & \multicolumn{2}{|c|}{0.045} \\
\hline Nutrient Composition & (\% Weight) & (\% Kcal) & (\% Weight) & (\% Kcal) \\
\hline Protein & 17.7 & 19.3 & $21.2^{\circ}$ & 18.7 \\
\hline Carbohydrate & 62.1 & 67.9 & 42.3 & 37.3 \\
\hline Fat & 5.2 & 12.8 & 22.2 & 44.0 \\
\hline Energy (Kcal/g) & \multicolumn{2}{|c|}{3.7} & \multicolumn{2}{|c|}{4.5} \\
\hline
\end{tabular}

${ }^{a}$ Values are calculated from ingredient analysis or manufacturer data (Harlan Laboratories). $n$-6HFD $=$ diet high in $n-6$ fatty acids; TBHQ = Tertiary butylhydroquinone.

\subsection{Cell Lines and Reagents}

Human colonic fetal human cells (FHC) were obtained from the American Type Culture Collection (Manassas, VA, USA) and maintained in Dulbecco's Modified Eagle's Medium (DMEM) from Sigma-Aldrich (St. Louis, MO, USA) supplemented with 10\% fetal calf serum (FCS) (Hyclone Laboratories, Logan, UT, USA) as described previously [26]. Linoleic acid and DCA were purchased from Sigma-Aldrich. At the end of the treatment period, cells were rinsed with PBS, precipitated by centrifugation, and stored at $-80{ }^{\circ} \mathrm{C}$ until further analysis. Western blotting was performed using antibodies for COX-2 (Cayman Chemical, Ann Arbor, MI, USA); c-JUN (Cell Signaling Technology, Danvers, MA, USA); histone deacetylase-1 (HDAC-1) and acetylated histone-3 (ACH3) (MilliporeSigma, Burlington, MA, USA); and FXR and $\beta$-ACTIN (Santa Cruz Biotechnology, Dallas, TX, USA).

\subsection{Real-Time PCR}

Colonic mucosa were scraped from the proximal colon as described previously [27], and total RNA was prepared using the Quick-RNA Miniprep Kit (Zymo Research, Irvine, CA, USA). The RNA concentration was assessed with the Nanodrop1000 Spectrophotomoter (Thermo Scientific, Waltham, MA, USA). Total RNA (500 ng) was used to prepare cDNA using qScript cDNA SuperMix (Quanta Biosciences, Gaithersburg, MD, USA). For PCR amplification of cDNA, we used the PerfeCTa SYBR Green Fast Mix, Rox (Quanta Biosciences). PCR reactions were performed at a final volume of $10 \mu \mathrm{L}$ comprising $5 \mu \mathrm{L}$ of SYBR Green Mix, forward and reverse primers $(1 \mu \mathrm{L}$ each, $10 \mathrm{nM}), 2 \mu \mathrm{L}$ nuclease-free water, and $1 \mu \mathrm{L}$ of cDNA. Glyceraldehyde 3-phosphate dehydrogenase (Gapdh) amplification was used for normalization of mRNA expression. The mouse primers (Sigma-Aldrich) used for RT-PCR are shown in Table 2. 
Table 2. The primers for RT-PCR and CpG methylation mouse studies.

\begin{tabular}{|c|c|}
\hline Target & Primer Sequence $^{a}$ \\
\hline \multicolumn{2}{|l|}{ mRNA: } \\
\hline$F x r$ & $\begin{array}{c}\text { F: TTAGTCTTCACCACAGCCACC } \\
\text { R: ACCTGTATACATACATTCAGCCAAC }\end{array}$ \\
\hline$A p c$ & $\begin{array}{l}\text { F: CTGAGCCTGGATGAGCCATT } \\
\text { R: GTGAGTCCAAGGCGAACGTC }\end{array}$ \\
\hline Pparr1 & $\begin{array}{l}\text { F: GTGAGACCAACAGCCTGACG } \\
\text { R: ACAGACTCGGCACTCAATGG }\end{array}$ \\
\hline Cox-2 & $\begin{array}{l}\text { F: GAAGTCTTTGGTCTGGTGCCT } \\
\text { R: GCTCCTGCTTGAGTATGTCG }\end{array}$ \\
\hline Gapdh & $\begin{array}{l}\text { F: CACTTGAAGGGTGGAGCCAA } \\
\text { R: AGTGATGGCATGGACTGTGG }\end{array}$ \\
\hline Ibabp & $\begin{array}{l}\text { F: CAGGAGACGTGATTGAAAGGG } \\
\text { R: GCCCCCAGAGTAAGACTGGG }\end{array}$ \\
\hline $\operatorname{Sh} p$ & $\begin{array}{l}\text { F: GTACCTGAAGGGCACGATCC } \\
\text { R: AGCCTCCTGTTGCAGGTGT }\end{array}$ \\
\hline Cond1 & $\begin{array}{l}\text { F: CTAAACAAGCACCCCCTCCA } \\
\text { R: GGTAACAGGGCTGTAGGCAC }\end{array}$ \\
\hline Methylation-sp & \\
\hline Fxr & $\begin{array}{c}\text { F: CGTTTAGCGATGGGGTTAATTAG } \\
\text { R: CGTCTTCTTTACTTATCTAAACCTCCTT }\end{array}$ \\
\hline$A p c$ & $\begin{array}{c}\text { F: GAGTGTGGTTGTCGGAAATTC } \\
\text { R: CAAAAAAACGTACATAAAAAACGCT }\end{array}$ \\
\hline Ptsg-2 & $\begin{array}{l}\text { F: TTTTAGTTAGGATTTTAGATTTCGG } \\
\text { R: ATAATACCAAAAAAACTACACCGC }\end{array}$ \\
\hline$\beta$-Actin & $\begin{array}{c}\text { F: AATAGTTATTTTAAGTATTTATGAAATAAG } \\
\text { R: TAACTACCTCAACACCTCAAC }\end{array}$ \\
\hline
\end{tabular}

${ }^{a} \mathrm{~F}=$ forward; $\mathrm{R}=$ reverse. $A p c=$ adenomatous polyposis Coli; $C o x-2=$ cyclooxygenase $-2 ; C c n d 1$ = cyclin D1; $F x r=$ farsenoid-X-receptor; $G a d p h=$ glyceraldehyde dehydrogenase phosphate; Ibabp = ileal bile acid-binding protein; $\operatorname{Par} \gamma 1$ = peroxisome proliferator-activated receptor $\gamma 1$; Ptsg-2 = prostaglandin-endoperoxide synthase-2; $\mathrm{Sh} p=$ small heterodimer protein.

\subsection{Genomic DNA Methylation}

The procedure for measurement of promoter methylation was described previously [26]. In short, genomic DNA was prepared from 10-15 mg of proximal colon mucosa using the DNeasy Blood and Tissue Kit (Qiagen, Valencia, CA, USA). The DNA $(1 \mu \mathrm{g})$ was modified via bisulfite treatment using the EpiTect Bisulfite Modification Kit (Qiagen) followed by PCR amplification using 1 cycle at $94{ }^{\circ} \mathrm{C}(1 \mathrm{~min}) ; 33-35$ cycles at $94{ }^{\circ} \mathrm{C}(30 \mathrm{~s}), 59{ }^{\circ} \mathrm{C}(30 \mathrm{~s})$, and $72{ }^{\circ} \mathrm{C}(1 \mathrm{~min})$; and 1 cycle at $72{ }^{\circ} \mathrm{C}$ (5 min). Amplification was performed at a volume of $25 \mu \mathrm{L}$ comprising bisulfite modified genomic DNA (50 ng), $0.4 \mu \mathrm{L}$ JumpStart Taq DNA polymerase (Sigma-Aldrich), $2.5 \mu \mathrm{L}$ 10X PCR buffer, $3.5 \mu \mathrm{L}$ $25 \mathrm{mM} \mathrm{MgCl}_{2}$ (final concentration $3.5 \mathrm{mM}$ ), $0.5 \mu \mathrm{L} 10 \mathrm{mM}$ dNTP mix (final concentration $200 \mu \mathrm{M}$ ), forward and reverse primers ( $1 \mu \mathrm{L}$ each), and water to a final volume of $25 \mu \mathrm{L}$. The PCR products were analyzed on $2 \%$ agarose gels and examined by ethidium bromide staining. The size and authenticity of the PCR products were confirmed by a molecular weight analysis and DNA sequencing. The primers (Sigma-Aldrich) used for DNA methylation studies are shown in Table 2.

\subsection{Statistical Analysis}

Densitometry analyses of PCR products were carried out using the Kodak ID Image Analysis Software (Eastman Kodak Company, Rochester, NY, USA). Expression and promoter methylation 
data were analyzed by ANOVA. Post-hoc multiple comparisons among all means were performed using Tukey's test after the main effects and interactions were confirmed to be significant at $p \leq 0.05$. Data are presented as means \pm standard error of the mean (SEM) and statistical differences highlighted with asterisks or different letters for multiple comparisons.

\section{Results}

\section{1. n-6HFD Induces Fxr Gene Promoter Hypomethylation and Expression in Proximal Colonic Mucosa}

Compared to animals assigned to the control diet $(5 \% \mathrm{E})$, mice fed the $n-6 \mathrm{HFD}(44 \% \mathrm{E})$ had higher weight gain $(\sim 10 \%)$ starting at week 4 through week 6 of the experiment (Figure $1 \mathrm{~A})$.
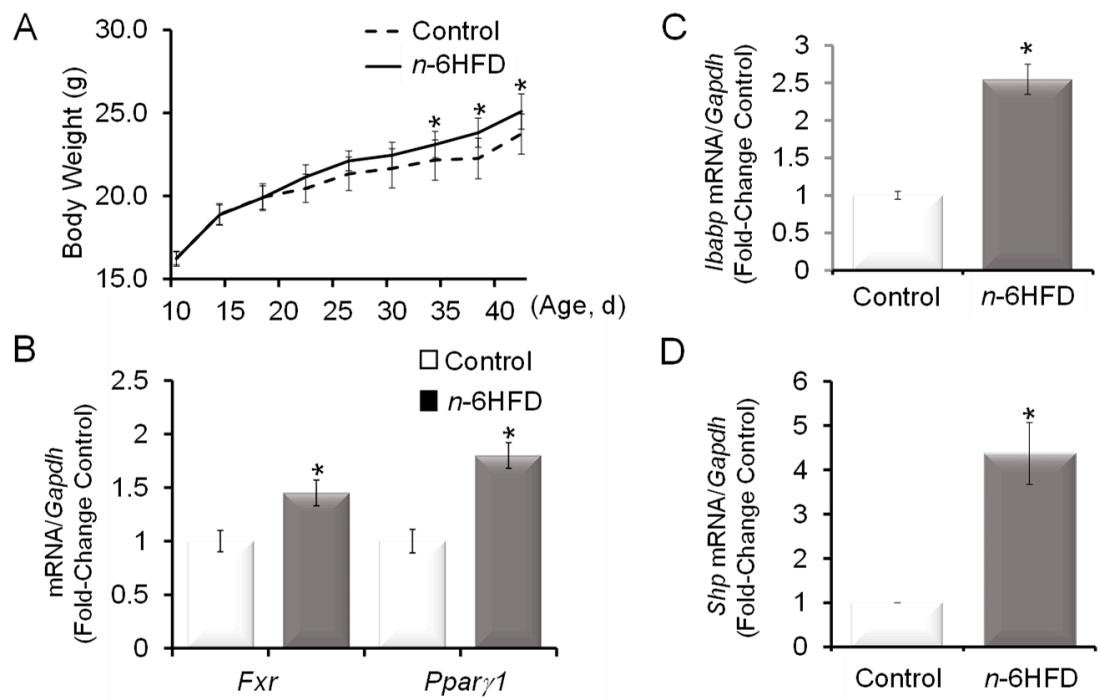

Figure 1. An $n$-6HFD (diet high in $n-6$ fatty acids) increases body weight and increases the expression of farnesoid-X-receptor (Fxr) in mouse colonic mucosa. (A) Weaned C57/BL6 male mice $(n=6)$ were assigned to a control diet containing $13 \%$ energy (13\%E, $5 \%$ by weight safflower oil (SO), $76 \%$ linoleic acid (LA)) or an $n$-6HFD containing 44 energy ( $44 \% \mathrm{E}, 22 \%$ by weight $\mathrm{SO}$ ) for 6 weeks. Bars represent means \pm standard error of the mean (SEM) of quantitation (fold change of control) of (B) Fxr and peroxisome proliferator-activated receptor $\gamma 1$ (Ppar 1$),(\mathbf{C})$ ileal bile acid-binding protein (Ibabp), and (D) small heterodimer protein (Shp) mRNA corrected for glyceraldehyde dehydrogenase phosphate (Gapdh) mRNA as an internal standard. Means \pm SEM (standard error of the mean) with an asterisk $\left(^{*}\right)$ differ $(p<0.05)$.

We examined the effects of the $n$-6HFD on Fxr mRNA expression in proximal colonic mucosa and found that Fxr transcripts were increased by $\sim 40 \%$ compared to animals fed the control diet (Figure 1B). As a control for changes in regulation of lipid metabolism, we monitored the expression of Ppar $\gamma 1$, which was increased by $\sim 80 \%$. The upregulation of Fxr and Pparr 1 were consistent with findings of previous reports documenting higher weight gain and increased levels of FXR in the distal small intestine in response to a high-fat diet (HFD) [28], and FXR-mediated transcriptional activation of Ppary [29]. We then turned our analysis to the intestinal gene targets for FXR, Ibabp, and Shp, whose expression was increased respectively 1.5- and 3.2-fold compared to the control (Figure 1C,D). Based on these results, we examined the impact of the $n-6 \mathrm{HFD}$ on the CpG methylation status of Fxr. We focused on a 470 bp promoter region $(-54 /+416)$ comprising $13 \mathrm{CpG}$ sites and flanking the transcription start site $(+1)$ of exon-3. This promoter generates FXR $\alpha 3 / 4$ transcripts (Figure $2 \mathrm{~A}$ ), which are expressed at higher levels than the FXR $\alpha 1 / 2$ mRNA variants in the intestine [20]. 
A

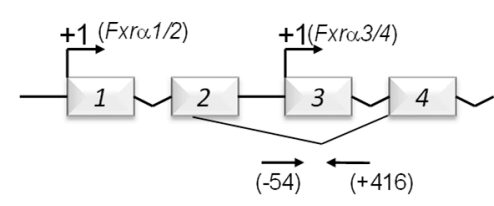

B

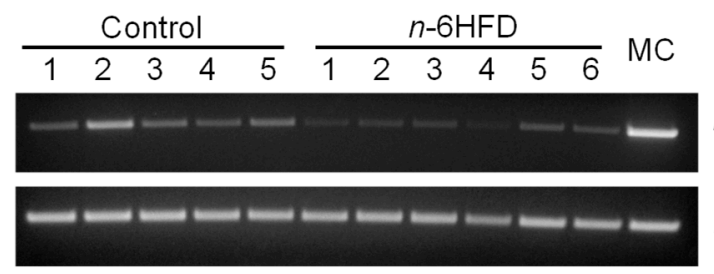

C

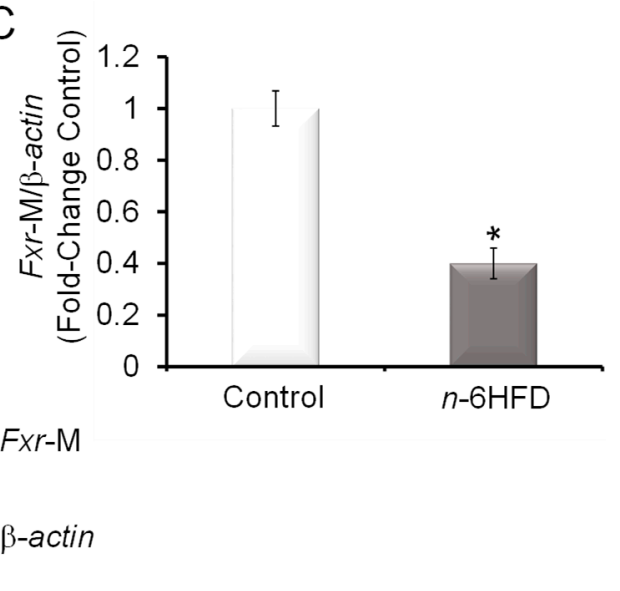

Figure 2. An $n$-6HFD induces Fxr CpG demethylation in mouse colonic mucosa. (A) Organization of the mouse Fxr gene. The top arrows indicate transcription start sites (+1) on exon-1 and exon-3. The bottom arrows indicate positions of oligonucleotides $(-54 /+416)$ around exon-3 used for CpG methylation studies [25]. (B) PCR bands amplified from bisulfonated genomic DNA obtained from proximal colonic mucosa with mouse Fxr-and $\beta$-actin-methylation (M)-specific primers. MC = methylation control. (C) Quantitation (fold-change/control) of Fxr promoter methylation status with control $(n=5)$ and $n$-6HFD $(n=6)$. Means \pm SEM with an asterisk differ $(p<0.05)$.

Amplification of CpG-methylated Fxr promoter amplicons from bisulfonated genomic colonic mucosal DNA was conducted in the linear range as reported previously [26]. The Fxr gene CpG methylation was reduced by $\sim 60 \%$ (Figure $2 \mathrm{~B}, \mathrm{C}$ ) in mice fed the $n-6 \mathrm{HFD}$, in agreement with a previous experimental report documenting increased intestinal FXR expression and BA levels as a result of feeding an HFD [30].

\section{2. n-6HFD Induces Ptsg-2 Gene Promoter Hypomethylation and Expression in Proximal Colonic Mucosa}

Cyclooxygenase-2 is a recognized risk factor in intestinal inflammation and CRC [31,32]. Levels of proximal colonic mucosal Cox-2 mRNA were increased $~ 1.5$-fold in mice fed the $n$-6HFD (Figure 3A). These results were consistent with other studies showing increased COX-2 expression associated with intestinal inflammation induced by an $n$-6HFD [33] and carcinogenesis of the colon [34,35]. Turning to the epigenetic regulation of the Ptsg-2 promoter (Figure 3B), feeding of the $n-6 \mathrm{HFD}$ to C57BL/6J mice reduced CpG methylation on average by $\sim 35 \%$ (Figure $3 B, C$ ).

The gain of Cox-2 mRNA levels and reduction in Ptsg-2 CpG methylation were paralleled by an accumulation of COX-2 protein (Figure 4A). As a positive control for activation of COX-2 expression by the $n-6 H F D$, we performed Western blotting of cell lysates from nontumor human FHC cells treated in culture with LA (Figure 4B), which induced COX-2 expression compared to control DMEM.

Taken together, these data suggest that exposure to an n-6HFD rich in LA elicits an inflammatory response characterized by CpG hypomethylation of Ptsg-2 and increased expression of COX-2. 

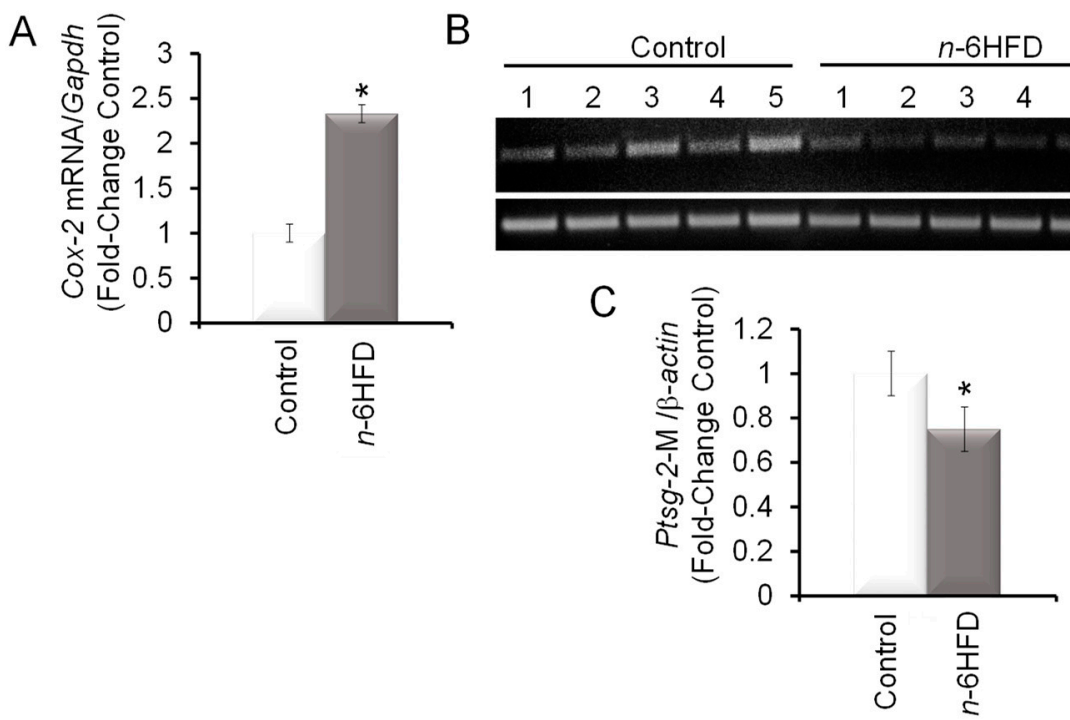

Figure 3. An n-6HFD induces Ptsg-2 (prostaglandin-endoperoxide synthase-2) CpG demethylation in mouse colonic mucosa. (A) The bars represent means \pm SEM of quantitation (fold change of control) of Cox-2 mRNA corrected for Gapdh mRNA as an internal standard. Means \pm SEM with an asterisk differ $(p<0.05)$. (B) PCR bands amplified from bisulfonated genomic DNA obtained from proximal colonic mucosa with mouse Ptsg-2- and $\beta$-actin-methylation (M)-specific primers. $\mathrm{MC}=$ methylation control. (C) Quantitation (fold-change/control) of Ptsg-2 promoter methylation status with control $(n=5)$ and $n$-6HFD $(n=6)$.

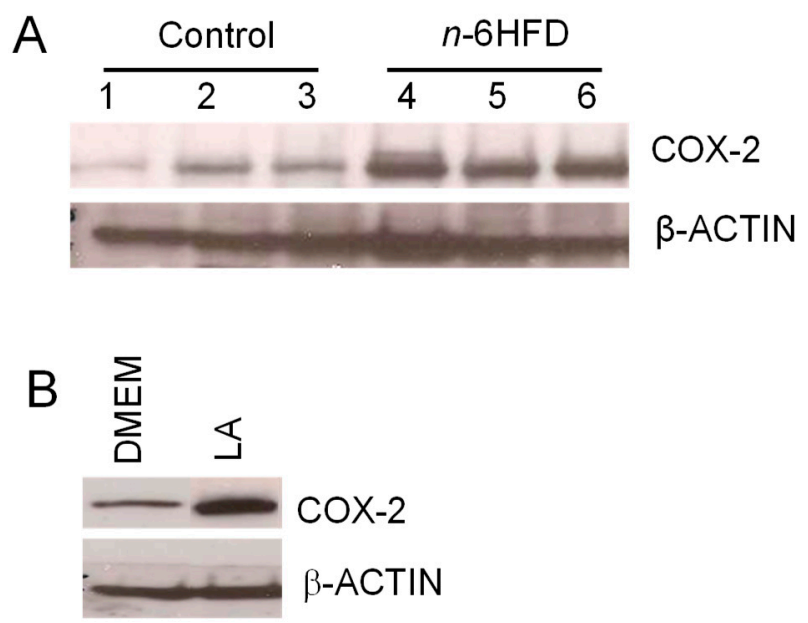

Figure 4. An n-6HFD induces COX-2 expression in mouse colonic mucosa. (A) The bands are representative immunocomplexes for COX-2 and internal control $\beta$-ACTIN in colonic mucosa of mice fed a control or an $n$-6HFD. (B) The bands are representative control immunocomplexes for COX-2 and internal control $\beta$-ACTIN from two separate experiments performed in triplicate in cell lysates of human fetal cells (FHC) cultured in control DMEM (Dulbecco's Modified Eagle's Medium) or DMEM plus LA (linoleic acid) $(75 \mu \mathrm{M})$ for $72 \mathrm{~h}$.

\section{3. $n$-6HFD Lowers the Expression of Apc and Activates Downstream Targets for the $\beta$-Catenin/Wnt Pathway}

The loss of APC along with the activation of the KRAS oncogene contribute to nuclear localization of $\beta$-catenin, a component of the Wnt signaling pathway, which promotes the expression of genes involved in proliferation [36-38]. An association between increased nuclear levels of $\beta$-catenin and COX-2 expression is seen in human and murine colon cancer cells with defective Apc [24,39]. We noted that the $n-6 H F D$ increased $A p c$ CpG methylation (Figure 5A) while reducing the Apc transcript levels (Figure 5B) in colonic mucosa. Because the Ccnd1 gene is a direct transcriptional target for activation by $\beta$-catenin transcription complexes $[40,41]$, we measured the levels of $C$ cnd 1 transcripts and found 
increased expression associated with the $n$-6HFD (Figure 5C). The upregulation of c-JUN, whose gene is also a direct target for transcriptional activation by $\beta$-catenin [42] and contributes to the activation of COX-2 [43], provided a positive control for activation of the Wnt signaling pathway under conditions of diminished Apc expression (Figure 5D). Finally, we noted that the $n$-6HFD reduced the colonic levels of histone deacetylase-1 (HDAC-1) while increasing the expression of acetylated histone 3 (ACH3), suggesting effects on epigenetic regulation.

A

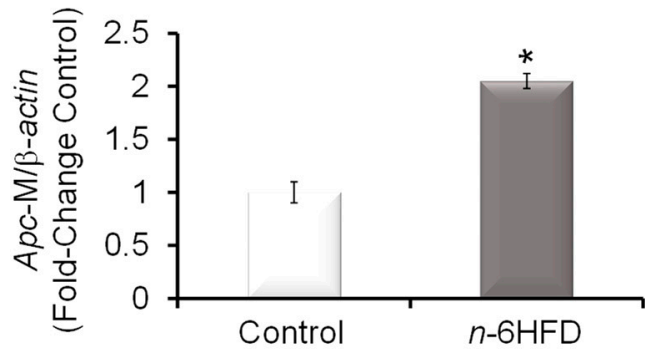

B

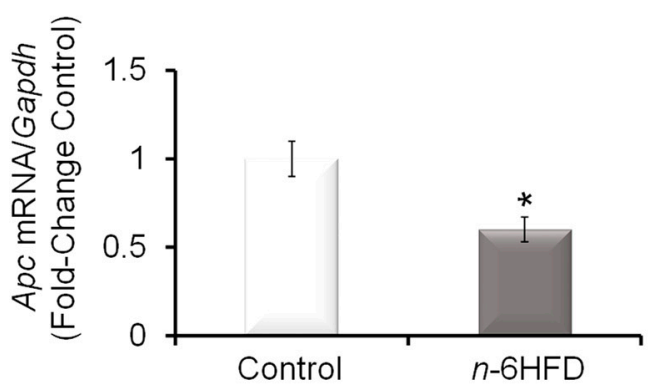

C

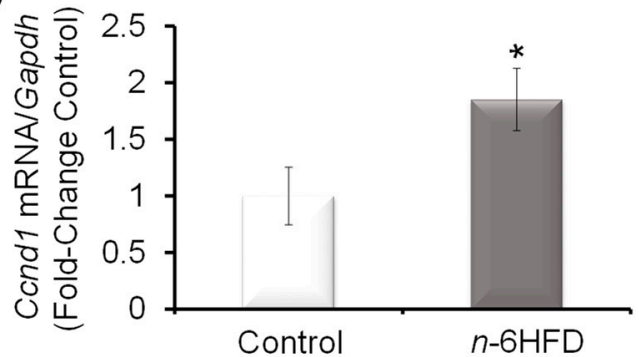

D

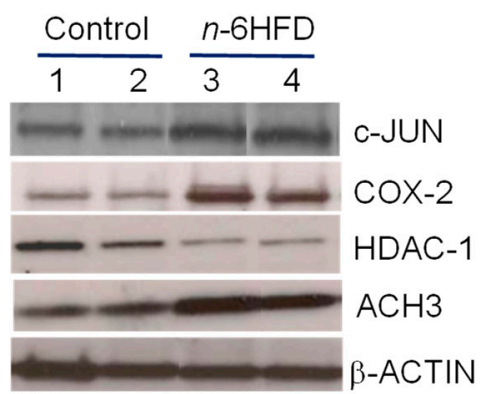

Figure 5. An $n$-6HFD induces $A p c$ CpG hypermethylation in mouse colonic mucosa. (A) Quantitation (fold-change/control) of $A p c$ promoter methylation status with control $(n=5)$ and $n$-6HFD $(n=6)$. (B) and (C) The bars represent respectively means \pm SEM of quantitation (fold change of control) of $A p c$ and Ccnd1 mRNA corrected for Gapdh mRNA as an internal standard. Means \pm SEM with an asterisk differ $(p<0.05)$. (D) The bands are representative immunocomplexes performed in duplicate for c-JUN, COX-2, histone deacetylase-1 (HDAC-1), acetylated histone 3 (ACH3), and internal control $\beta$-ACTIN in colonic mucosa of mice fed a control or $n$-6HFD.

In summary, these results suggest that an $n$-6HFD rich in LA epigenetically alters gene expression in colonic mucosa, leading to an accumulation of proinflammatory and proliferative factors associated with a higher risk of CRC.

\section{Discussion}

In this study, we first address whether or not changes in Fxr promoter CpG methylation contribute to the regulation of Fxr expression in the colonic mucosa in response to an $n-6 \mathrm{HFD}$, which mimics dietary fat exposure known to increase the risk of intestinal inflammation in humans $[3,4]$. The total energy as fat $(44 \% \mathrm{E})$ of the $n-6 \mathrm{HFD}$ approaches the one used in previous mouse models that linked inflammation to the development of CRC $[44,45]$. We show that feeding of the $n-6 H F D$ to C57BL/ 6 mice reduces Fxr promoter CpG methylation while increasing the expression of Fxr and that of the FXR-target genes Ibabp and Shp. These results suggest that conditions that have been demonstrated to increase the intestinal levels of BA $[9,10,30]$ direct the removal of repressive methylation marks at the Fxr gene to augment FXR expression and maintain BA homeostasis. We also show that the $n$-6HFD induces Ppar 1 expression in the colonic mucosa. The upregulation of Ppar 1 by the $n-6 \mathrm{HFD}$ is consistent with the results of previous investigations documenting transactivation of the Ppar $\gamma$ gene by FXR through its physical interaction with an FXR response element [29], and genetic evidence that PPAR $\gamma$ expression is compromised in FXR-deficient $\left(F x r^{-/-}\right)$models [46]. The stimulatory action of 
FXR on the PPAR $\gamma$ gene is believed to reduce the steady-state levels of $\beta$-catenin in intestinal cells with normal $A p c[47,48]$. In addition, we report that the $n$-6HFD increases COX-2 expression associated with CpG hypomethylation at the Ptsg-2 gene. In esophageal and gastrointestinal cells, BA increase the expression of COX-2 through various signals, including the p38-mitogen-activated protein kinase (p38MAPK) pathway [49] and the transcription factors nuclear factor kappa-light-chain-enhancer of activated B (NFkB) [50] and activator protein-1 (AP-1) [49,51]. Interestingly, SHP, a transcription factor whose expression is induced by FXR, interacts physically with and functions as a positive coactivator of NFkB [52], and is required for caudal-related homeobox-1 gene (CDX1)-mediated activation of COX-2 [53]. Therefore, the activation of FXR associated with chronic exposure to higher levels of BA due to the $n$-6HFD may have the adverse effect of triggering an inflammatory response supported by SHP, which in turn may override the anti-inflammatory activities of FXR on NFkB [54]. Moreover, the increased COX-2 expression is expected to support the enzymatic conversion of arachidonic acid (AA) to prostaglandin E2 (PGE2), which, through its EP2 and EP4 receptors, may activate the phosphoinositide 3-kinase (PI3K)/protein kinase B (Akt)-dependent upregulation of $\beta$-catenin. This may lead to further activation of COX-2 expression [55,56]. Thus, the long-term exposure to an $n$-6HFD rich in LA may trigger an intestinal feed-forward loop through which BA amplifies COX-2 transcription mediated by the transcription factors $\beta$-catenin, SHP, and AP-1. In support of this hypothesis, we also show that the n-6HFD increases the expression of c-JUN, a key component of the AP-1 transcription factor [57]. Based on this cumulative evidence, we propose that accumulation of SHP and c-JUN coupled to CpG hypomethylation at the Ptsg-2 gene may serve as a biomarker of increased risk of intestinal inflammation and tumorigenesis related to chronic exposure to an $n$-6HFD [58,59]. In accord with this suggestion, changes in DNA methylation profiles of genes involved in lipid metabolism and inflammation have been proposed as candidate biomarkers of CRC [14].

A second question addressed by this study pertains to whether or not feeding an $n$-6HFD epigenetically alters the expression of $A p c$ and $\beta$-catenin signaling in the colonic mucosa. The rationale for this objective stems from earlier experimental evidence showing that colonic inflammation due to an HFD is paralleled by an increase in the gastro-intestinal levels of $\beta$-catenin [60-62] and the activation by the $\beta$-catenin/transcription factor (TCF)/lymphoid enhancer binding factor (LEF) transcription complex of genes (e.g., Ccnd1) involved in intestinal tumorigenesis $[45,63,64]$. We show that the CpG hypermethylation of the Apc gene in colonic mucosa of mice fed the $n$-6HFD correlates with reduced $A p c$ expression, and an accumulation of $C c n d 1$ and c-JUN, which are established transcription targets for the $\beta$-catenin/TC/LEF transcription complex [40,41]. The latter is constitutively active in $A p c$-deficient colon carcinoma [65-67]. One question raised by our data relates to the mechanisms contributing to the silencing of $A p c$ in colonic mucosa of mice fed the $n$-6HFD. The enrichment in c-JUN and downregulation of Apc expression correlate in this study with a reduction in HDAC-1 and a gain in AcH3. These changes underscore the impact of dietary conditions that promote obesity, such as the weight gain observed in this study, on epigenetic regulation in the colonic mucosa [68]. Obesity induces DNA hypermethylation of $A p c$ in the small intestine and changes the epigenetic landscape in the colonic epithelium [69], thus enhancing proliferation mediated by the Wnt/ $\beta$-catenin pathway [70-72]. Studies in patients with gastric adenomas [73] and CRC cell lines [74] have confirmed the existence of a positive association between an accumulation of $\beta$-catenin and hypermethylation of the Apc gene. Recently, $\sim 69 \%$ of CRCs were reported to harbor hypermethylated Apc [75], which correlated positively with tumor size and lymph node metastasis. To our knowledge, this is the first report showing a direct effect of an n-6HFD on epigenetic disregulation of $A p c$ and Pstg-2 via CpG methylation in the colonic mucosa. These epigenetic modifications may be useful in monitoring the susceptibility to CRC associated with the adoption of an $n$-6HFD and overweight conditions.

\section{Conclusions}

In summary, the current study provides evidence that an $n$-6HFD contributes epigenetically to the activation of FXR expression via CpG demethylation to support the expression of genes whose 
products (i.e., SHP, IBABP) participate in the regulation of BA homeostasis through the enterohepatic circulation (Figure 6). Our data also suggest that chronic exposure to an n-6HFD downregulates APC expression via $\mathrm{CpG}$ hypermethylation and this associates with increased expression of COX-2 via PTSG-2 CpG hypomethylation and accumulation of C-JUN and CCND1, thus increasing the risk of inflammation and cancer of the colon.

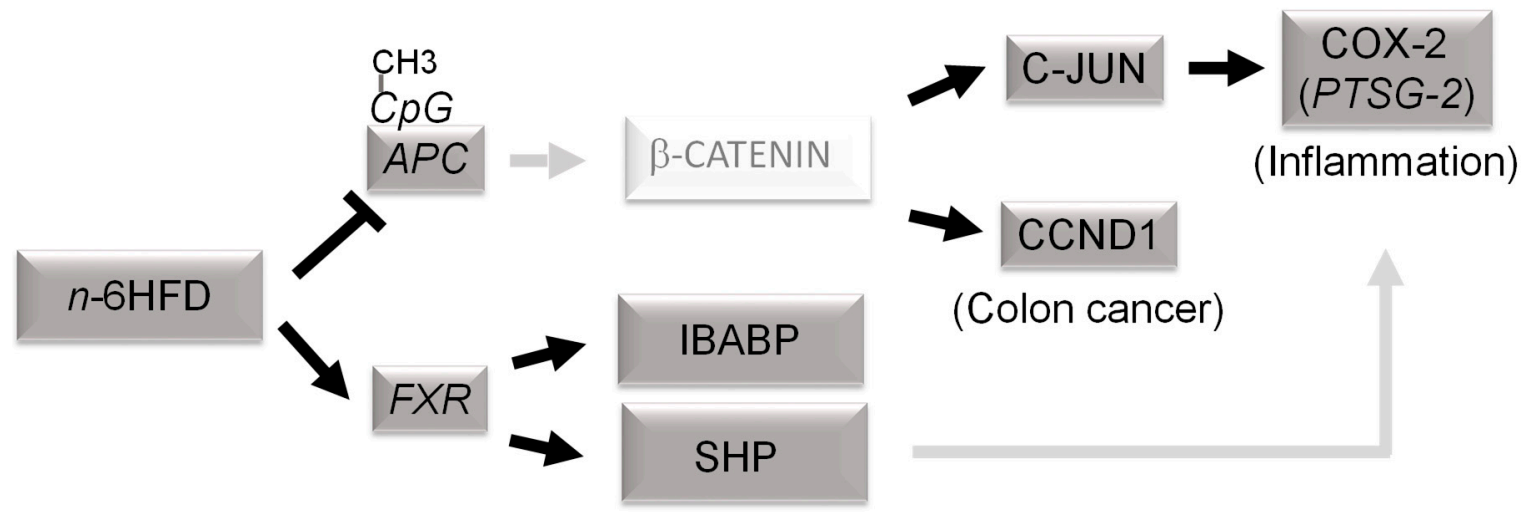

Figure 6. Proposed epigenetic model of colonic inflammation and carcinogenesis associated with long-term exposure to a diet high in $n-6$ fatty acids (n-6HFD). Chronic exposure to an $n$-6HFD impairs adenomatous polyposis Coli $(A P C)$ expression through $\mathrm{CpG}$ hypermethylation $\left(\mathrm{CpG}-\mathrm{CH}_{3}\right)$. This favors the activation of downstream targets of the $\beta$-catenin/Wnt pathway, supporting increased expression of genes involved in inflammation (c-JUN, PTSG-2) and proliferation such as cyclin D1 (CCND1). The factors in dark grey boxes refer to changes in expression from the current study. The involvement of $\beta$-catenin and upregulation of cyclooxygenase-2 (COX-2) by small heterodimer protein (SHP) are suggested based on published studies mentioned in the Discussion. FXR = farnesoid-X-receptor; IBABP $=$ ileal bile acid-binding protein.

Studies are ongoing in our laboratory to clarify the impact of diets that vary in their fatty acid profile (i.e., $n-6$ versus $n-3$ ) on CpG methylation of the Fxr and Cox-2 genes and effects on the expression of FXR- and $\beta$-catenin target genes. Future investigators should elucidate how an $n$-6HFD modifies the interplay between microbiota and epigenetics of inflammation and colon cancer. For example, a diet mimicking the human Mediterranean diet, which is rich in olive oil, fruits, and vegetables, favors a microbiota composition associated with reduced carcinogenesis in intestinal cells with defective $A p c$ [76]. Progress in these areas may help to address the question of whether the adoption of an $n-6 H F D$ associates with a higher risk of IBD and CRC and provide new strategies for epigenetic targeting through dietary interventions.

Author Contributions: O.I.S., T.C.D., and D.F.R. contributed to the conception and design of the animal experiments and the collection of animal tissues and analyses. M.G.D. contributed to the cell culture experiments and laboratory analyses. D.F.R. and O.I.S. wrote the manuscript. All authors read and approved the final version of this manuscript.

Funding: This work was supported by a grant from NIFA, GRANT12445471; the Arizona Cancer Center Support Grant P30CA23074; and the Cancer Biology Training Grant T32CA009213.

Acknowledgments: This work was supported by a predoctoral training grant to M.G.D. from the Cancer Biology Training Grant T32CA009213.

Conflicts of Interest: The authors of this manuscript have no conflicts of interest.

\section{References}

1. Owczarek, D.; Rodacki, T.; Domagała-Rodacka, R.; Cibor, D.; Mach, T. Diet and nutritional factors in inflammatory bowel diseases. World J. Gastroenterol. 2016, 22, 895-905. [CrossRef]

2. Mills, S.C.; Windsor, A.C.; Knight, S.C. The potential interactions between polyunsaturated fatty acids and colonic inflammatory processes. Clin. Exp. Immunol. 2005, 142, 216-228. [CrossRef] [PubMed] 
3. Tjonneland, A.; Overvad, K.; Bergmann, M.M.; Nagel, G.; Linseisen, J.; Hallmans, G.; Palmqvist, R.; Sjodin, H.; Hagglund, G.; Berglund, G.; et al. Linoleic acid, a dietary n-6 polyunsaturated fatty acid, and the aetiology of ulcerative colitis: A nested case-control study within a European prospective cohort study. Gut 2009, 58, 1606-1611. [PubMed]

4. Ueda, Y.; Kawakami, Y.; Kunii, D.; Okada, H.; Azuma, M.; Le, D.S.; Yamamoto, S. Elevated concentrations of linoleic acid in erythrocyte membrane phospholipids in patients with inflammatory bowel disease. Nutr. Res. 2008, 28, 239-244. [CrossRef] [PubMed]

5. Caderni, G.; Bianchini, F.; Dolara, P.; Kriebel, D. Proliferative activity in the colon of the mouse and its modulation by dietary starch, fat, and cellulose. Cancer Res. 1989, 49, 1655-1659. [PubMed]

6. Caderni, G.; Stuart, E.W.; Bruce, W.R. Dietary factors affecting the proliferation of epithelial cells in the mouse colon. Nutr. Cancer 1988, 11, 147-153. [CrossRef]

7. Reddy, B.S.; Mangat, S.; Sheinfil, A.; Weisburger, J.H.; Wynder, E.L. Effect of type and amount of dietary fat and 1,2-dimethylhydrazine on biliary bile acids, fecal bile acids, and neutral sterols in rats. Cancer Res. 1977, 37, 2132-2137.

8. Reddy, B.S.; Watanabe, K.; Weisburger, J.H.; Wynder, E.L. Promoting effect of bile acids in colon carcinogenesis in germ-free and conventional F344 rats. Cancer Res. 1977, 37, 3238-3242.

9. Imray, C.H.; Radley, S.; Davis, A.; Barker, G.; Hendrickse, C.W.; Donovan, I.A.; Lawson, A.M.; Baker, P.R.; Neoptolemos, J.P. Faecal unconjugated bile acids in patients with colorectal cancer or polyps. Gut 1992, 33, 1239-1245. [CrossRef]

10. Bayerdörffer, E.; Mannes, G.A.; Richter, W.O.; Ochsenkühn, T.; Wiebecke, B.; Köpcke, W.; Paumgartner, G. Increased serum deoxycholic acid levels in men with colorectal adenomas. Gastroenterology 1993, 104, 145-151. [CrossRef]

11. Hill, M.J.; Drasar, B.S.; Hawksworth, G.; Aries, V.; Crowther, J.S.; Williams, R.E. Bacteria and aetiology of cancer of large bowel. Lancet 1971, 1, 95-100. [CrossRef]

12. Hill, M.J.; Drasar, B.S.; Williams, R.E.; Meade, T.W.; Cox, A.G.; Simpson, J.E.; Morson, B.C. Faecal bile-acids and clostridia in patients with cancer of the large bowel. Lancet 1975, 305, 535-539. [CrossRef]

13. American Cancer Society. Cancer Facts E Figures 2018; American Cancer Society: Atlanta, GA, USA, 2018.

14. Silviera, M.L.; Smith, B.P.; Powell, J.; Sapienza, C. Epigenetic differences in normal colon mucosa of cancer patients suggest altered dietary metabolic pathways. Cancer Prev. Res. 2012, 5, 374-384. [CrossRef] [PubMed]

15. Willett, W.C. Diet and cancer. Oncology 2000, 5, 393-404.

16. Khan, N.; Afaq, F.; Mukhtar, H. Lifestyle as risk factor for cancer: Evidence from human studies. Cancer Lett. 2010, 293, 133-143. [CrossRef] [PubMed]

17. Modica, S.; Gadaleta, R.M.; Moschetta, A. Deciphering the nuclear bile acid receptor FXR paradigm. Nucl. Recept. Signal. 2010, 8, e005. [CrossRef] [PubMed]

18. De Gottardi, A.; Touri, F.; Maurer, C.A.; Perez, A.; Maurhofer, O.; Ventre, G.; Bentzen, C.L.; Niesor, E.J.; Dufour, J.F. The bile acid nuclear receptor FXR and the bile acid binding protein IBABP are differently expressed in colon cancer. Dig. Dis. Sci. 2004, 49, 982-989. [CrossRef] [PubMed]

19. Lax, S.; Schauer, G.; Prein, K.; Kapitan, M.; Silbert, D.; Berghold, A.; Berger, A.; Trauner, M. Expression of the nuclear bile acid receptor/farnesoid $\mathrm{X}$ receptor is reduced inhuman colon carcinoma compared to nonneoplastic mucosa independent from site and may be associated with adverse prognosis. Int. J. Cancer 2012, 130, 2232-2239. [CrossRef]

20. Modica, S.; Murzilli, S.; Salvatore, L.; Schmidt, D.R.; Moschetta, A. Nuclear Bile Acid Receptor FXR protects against intestinal tumorigenesis. Cancer Res. 2008, 68, 9589-9594. [CrossRef]

21. Maran, R.R.; Thomas, A.; Roth, M.; Sheng, Z.; Esterly, N.; Pinson, D.; Gao, X.; Zhang, Y.; Ganapathy, V.; Gonzalez, F.J.; et al. Farnesoid $X$ receptor deficiency in mice leads to increased intestinal epithelial cell proliferation and tumor development. J. Pharm. Exp. 2009, 328, 469-477. [CrossRef]

22. Liu, Y.; Sun, H.; Hu, M.; Zhang, Y.; Chen, S.; Tighe, S.; Zhu, Y. The role of cyclooxygenase-2 in colorectal carcinogenesis. Clin. Colorectal Cancer 2017, 16, 165-172. [CrossRef] [PubMed]

23. Yang, K.; Li, H.; Dong, J.; Dong, Y.; Wang, C.Z. Expression profile of polyunsaturated fatty acids in colorectal cancer. World J. Gastroenterol. 2015, 21, 2405-2412. [CrossRef] [PubMed]

24. Dimberg, J.; Hugander, A.; Sirsjö, A.; Söderkvist, P. Enhanced expression of cyclooxygenase-2 and nuclear beta-catenin are related to mutations in the APC gene in human colorectal cancer. Anticancer Res. 2001, 21, 911-915. [PubMed] 
25. Suzuki, R.; Miyamoto, S.; Yasui, Y.; Sugie, S.; Tanaka, T. Global gene expression analysis of the mouse colonic mucosa treated with azoxymethane and dextran sodium sulfate. BMC Cancer 2007, 7, 84. [CrossRef] [PubMed]

26. Selmin, O.I.; Fang, C.; Lyon, A.M.; Doetschman, T.C.; Thompson, P.A.; Martinez, J.D.; Smith, J.W.; Lance, P.M.; Romagnolo, D.F. Inactivation of Adenomatous Polyposis Coli Reduces Bile Acid/Farnesoid X Receptor Expression through Fxr gene CpG Methylation in Mouse Colon Tumors and Human Colon Cancer Cells. J. Nutr. 2016, 146, 236-242. [CrossRef] [PubMed]

27. Kellermayer, R.; Dowd, S.E.; Harris, R.A.; Balasa, A.; Schaible, T.D.; Wolcott, R.D.; Tatevian, N.; Szigeti, R.; $\mathrm{Li}, \mathrm{Z}$; Versalovic, J.; et al. Colonic mucosal DNA methylation, immune response, and microbiome patterns in Toll-like receptor 2-knockout mice. FASEB J. 2011, 25, 1449-1460. [CrossRef] [PubMed]

28. de Wit, N.J.; Bosch-Vermeulen, H.; de Groot, P.J.; Hooiveld, G.J.; Bromhaar, M.M.; Jansen, J.; Müller, M.; van der Meer, $\mathrm{R}$. The role of the small intestine in the development of dietary fat-induced obesity and insulin resistance in C57BL/6J mice. BMC Med. Genom. 2008, 1, 14. [CrossRef] [PubMed]

29. Renga, B.; Mencarelli, A.; Migliorati, M.; Cipriani, S.; D'Amore, C.; Distrutti, E.; Fiorucci, S. SHP-dependent and -independent induction of peroxisome proliferator-activated receptor- $\gamma$ by the bile acid sensor farnesoid $\mathrm{X}$ receptor counter-regulates the pro-inflammatory phenotype of liver myofibroblasts. Inflamm. Res. 2011, 60, 577-587. [CrossRef]

30. Stenman, L.K.; Holma, R.; Korpela, R. High-fat-induced intestinal permeability dysfunction associated with altered fecal bile acids. World J. Gastroenterol. 2012, 18, 923-929. [CrossRef]

31. William, C.S.; Mann, M.; Dubois, R.N. The role of cycloxygenases in inflammation, cancer and development. Oncogene 1999, 18, 7906-7916.

32. Romagnolo, D.F.; Papoutsis, A.J.; Selmin, O. Nutritional targeting of cyclooxygenase-2 for colon cancer prevention. Inflamm. Allergy Drug Targets 2010, 9, 181-191. [CrossRef] [PubMed]

33. Reddy, K.V.; Naidu, K.A. Maternal and neonatal dietary intake of balanced n-6/n-3 fatty acids modulates experimental colitis in young adult rats. Eur. J. Nutr. 2016, 55, 1875-1890. [CrossRef] [PubMed]

34. Sano, H.; Kawahito, Y.; Wilder, R.L.; Hashiramoto, A.; Mukai, S.; Asai, K.; Kimura, S.; Kato, H.; Kondo, M.; Hla, T. Expression of cyclooxygenase-1 and -2 in human colorectal cancer. Cancer Res. 1995, 55, 3785-3789. [PubMed]

35. DuBois, R.N.; Radhika, A.; Reddy, B.S.; Entingh, A.J. Increased cyclooxygenase-2 levels in carcinogen-induced rat colonic tumors. Gastroenterology 1996, 110, 1259-1262. [CrossRef] [PubMed]

36. Kulendran, M.; Stebbing, J.F.; Marks, C.G.; Rockall, T.A. Predictive and prognostic factors in colorectal cancer: A personalized approach. Cancers 2011, 3, 1622-1638. [CrossRef]

37. Markowitz, S.D.; Bertagnolli, M.M. Molecular origins of cancer: Molecular basis of colorectal cancer. N. Engl. J. Med. 2009, 361, 2449-2460. [CrossRef]

38. Phelps, R.A.; Chidester, S.; Dehghanizadeh, S.; Phelps, J.; Sandoval, I.T.; Rai, K.; Broadbent, T.; Sarkar, S.; Burt, R.W.; Jones, D.A. A two-step model for colon adenoma initiation and progression caused by APC loss. Cell 2009, 137, 623-634. [CrossRef]

39. Mei, J.M.; Hord, N.G.; Winterstein, D.F.; Donald, S.P.; Phang, J.M. Differential expression of prostaglandin endoperoxide $\mathrm{H}$ synthase-2 and formation of activated beta-catenin-Lef-1 transcription complex in mouse colonic epithelial cells contrasting in APC. Carcinogenesis 1999, 20, 737-740. [CrossRef]

40. Tetsu, O.; McCormick, F. Beta-catenin regulates expression of cyclin D1 in colon carcinoma cells. Nature 1999, 398, 422-426. [CrossRef]

41. Shtutman, M.; Zhurinsky, J.; Simcha, I.; Albanese, C.; D'Amico, M.; Pestell, R.; Ben-Ze'ev, A. The cyclin D1 gene is a target of the beta-catenin/LEF-1 pathway. Proc. Natl. Acad. Sci. USA 1999, 96, 5522-5527. [CrossRef]

42. Mann, B.; Gelos, M.; Siedow, A.; Hanski, M.L.; Gratchev, A.; Ilyas, M.; Bodmer, W.F.; Moyer, M.P.; Riecken, E.O.; Buhr, H.J.; et al. Target genes of beta-catenin-T cell-factor/lymphoid-enhancer-factor signaling in human colorectal carcinomas. Proc. Natl. Acad. Sci. USA 1999, 96, 1603-1608. [CrossRef] [PubMed]

43. Degner, S.C.; Kemp, M.Q.; Bowden, G.T.; Romagnolo, D.F. Conjugated linoleic acid attenuates cyclooxygenase-2 transcriptional activity via an anti-AP-1 mechanism in MCF-7 breast cancer cells. J. Nutr. 2006, 136, 421-427. [CrossRef] [PubMed]

44. Day, S.D.; Enos, R.T.; McClellan, J.L.; Steiner, J.L.; Velázquez, K.T.; Murphy, E.A. Linking inflammation to tumorigenesis in a mouse model of high-fat-diet-enhanced colon cancer. Cytokine 2013, 64, 454-462. [CrossRef] [PubMed] 
45. Tang, F.Y.; Pai, M.H.; Chiang, E.P. Consumption of high-fat diet induces tumor progression and epithelial-mesenchymal transition of colorectal cancer in a mouse xenograft model. J. Nutr. Biochem. 2012, 23, 1302-1313. [CrossRef] [PubMed]

46. Abdelkarim, M.; Caron, S.; Duhem, C.; Prawitt, J.; Dumont, J.; Lucas, A.; Bouchaert, E.; Briand, O.; Brozek, J.; Kuipers, F.; et al. The farnesoid $\mathrm{X}$ receptor regulates adipocyte differentiation and function by promoting peroxisome proliferator-activated receptor-gamma and interfering with the Wnt/beta-catenin pathways. J. Biol. Chem. 2010, 285, 36759-36767. [CrossRef]

47. Panza, A.; Pazienza, V.; Ripoli, M.; Benegiamo, G.; Gentile, A.; Valvano, M.R.; Augello, B.; Merla, G.; Prattichizzo, C.; Tavano, F.; et al. Interplay between SOX9, $\beta$-catenin and PPAR $\gamma$ activation in colorectal cancer. Biochim. Biophys. Acta 2013, 1833, 1853-1865. [CrossRef] [PubMed]

48. Girnun, G.D.; Smith, W.M.; Drori, S.; Sarraf, P.; Mueller, E.; Eng, C.; Nambiar, P.; Rosenberg, D.W.; Bronson, R.T.; Edelmann, W.; et al. APC-dependent suppression of colon carcinogenesis by PPARgamma. Proc. Natl. Acad. Sci. USA 2002, 99, 13771-13776. [CrossRef]

49. Looby, E.; Abdel-Latif, M.M.; Athié-Morales, V.; Duggan, S.; Long, A.; Kelleher, D. Deoxycholate induces COX-2 expression via Erk1/2-, p38-MAPK and AP-1-dependent mechanisms in esophageal cancer cells. BMC Cancer 2009, 9, 190. [CrossRef]

50. Abdel-Latif, M.M.; Inoue, H.; Kelleher, D.; Reynolds, J.V. Factors regulating nuclear factor-kappa B activation in esophageal cancer cells: Role of bile acids and acid. J. Cancer Res. Ther. 2016, 12, 364-373.

51. Glinghammar, B.; Rafter, J. Colonic luminal contents induce cyclooxygenase 2 transcription in human colon carcinoma cells. Gastroenterology 2001, 120, 401-410. [CrossRef]

52. Kim, Y.S.; Han, C.Y.; Kim, S.W.; Kim, J.H.; Lee, S.K.; Jung, D.J.; Park, S.Y.; Kang, H.; Choi, H.S.; Lee, J.W.; et al. The orphan nuclear receptor small heterodimer partner as a novel coregulator of nuclear factor-kappa b in oxidized low density lipoprotein-treated macrophage cell line RAW 264.7. J. Biol. Chem. 2001, 276, 33736-33740. [CrossRef] [PubMed]

53. Park, M.J.; Kim, K.H.; Kim, H.Y.; Kim, K.; Cheong, J. Bile acid induces expression of COX-2 through the homeodomain transcription factor CDX1 and orphan nuclear receptor SHP in human gastric cancer cells. Carcinogenesis 2008, 29, 2385-2393. [CrossRef] [PubMed]

54. Wang, Y.D.; Chen, W.D.; Wang, M.; Yu, D.; Forman, B.M.; Huang, W. Farnesoid X receptor antagonizes nuclear factor kappa B in hepatic inflammatory response. Hepatology 2008, 48, 1632-1643. [CrossRef]

55. Hsu, H.H.; Lin, Y.M.; Shen, C.Y.; Shibu, M.A.; Li, S.Y.; Chang, S.H.; Lin, C.C.; Chen, R.J.; Viswanadha, V.P.; Shih, H.N.; et al. Prostaglandin E2-Induced COX-2 Expressions via EP2 and EP4 Signaling Pathways in Human LoVo Colon Cancer Cells. Int. J. Mol. Sci. 2017, 18, 1132. [CrossRef] [PubMed]

56. Lim, K.; Han, C.; Xu, L.; Isse, K.; Demetris, A.J.; Wu, T. Cyclooxygenase-2-derived prostaglandin E2 activates beta-catenin in human cholangiocarcinoma cells: Evidence for inhibition of these signaling pathways by omega 3 polyunsaturated fatty acids. Cancer Res. 2008, 68, 553-560. [CrossRef] [PubMed]

57. Behrens, A.; Jochum, W.; Sibilia, M.; Wagner, E.F. Oncogenic transformation by ras and fos is mediated by c-Jun N-terminal phosphorylation. Oncogene 2000, 19, 2657-2663. [CrossRef]

58. Geerling, B.J.; Dagnelie, P.C.; Badart-Smook, A.; Russel, M.G.; Stockbrügger, R.W.; Brummer, R.J. Diet as a risk factor for the development of ulcerative colitis. Am. J. Gastroenterol. 2000, 95, 1008-1013. [CrossRef]

59. Bailey, A.M.; Zhan, L.; Maru, D.; Shureiqi, I.; Pickering, C.R.; Kiriakova, G.; Izzo, J.; He, N.; Wei, C.; Baladandayuthapani, V; et al. FXR silencing in human colon cancer by DNA methylation and KRAS signaling. Am. J. Physiol. Gastrointest. Liver Physiol. 2014, 306, G48-G58. [CrossRef]

60. Zeng, H.; Ishaq, S.L.; Zhao, F.Q.; Wright, A.G. Colonic inflammation accompanies an increase of $\beta$-catenin signaling and Lachnospiraceae/Streptococcaceae bacteria in the hind gut of high-fat diet-fed mice. J. Nutr. Biochem. 2016, 35, 30-36. [CrossRef]

61. Penrose, H.M.; Heller, S.; Cable, C.; Nakhoul, H.; Baddoo, M.; Flemington, E.; Crawford, S.E.; Savkovic, S.D. High-fat diet induced leptin and Wnt expression: RNA-sequencing and pathway analysis of mouse colonic tissue and tumors. Carcinogenesis 2017, 38, 302-311. [CrossRef]

62. Arita, S.; Kinoshita, Y.; Ushida, K.; Enomoto, A.; Inagaki-Ohara, K. High-fat diet feeding promotes stemness and precancerous changes in murine gastric mucosa mediated by leptin receptor signaling pathway. Arch. Biochem. Biophys. 2016, 610, 16-24. [CrossRef] [PubMed] 
63. Mao, J.; Hu, X.; Xiao, Y.; Yang, C.; Ding, Y.; Hou, N.; Wang, J.; Cheng, H.; Zhang, X. Overnutrition stimulates intestinal epithelium proliferation through B-catenin signaling in obese mice. Diabetes 2013, 62, 3736-3746. [CrossRef] [PubMed]

64. Zhu, Q.C.; Gao, R.Y.; Wu, W.; Guo, B.M.; Peng, J.Y.; Qin, H.L. Effect of a high-fat diet in development of colonic adenoma in an animal model. World. J. Gastroenterol. 2014, 20, 8119-8129. [CrossRef] [PubMed]

65. Korinek, V.; Barker, N.; Morin, P.J.; van Wichen, D.; de Weger, R.; Kinzler, K.W.; Vogelstein, B.; Clevers, H. Constitutive transcriptional activation by a beta-catenin-Tcf complex in APC - / - colon carcinoma. Science 1997, 275, 1784-1787. [CrossRef]

66. Morin, P.J.; Sparks, A.B.; Korinek, V.; Barker, N.; Clevers, H.; Vogelstein, B.; Kinzler, K.W. Activation of beta-catenin-Tcf signaling in colon cancer by mutations in beta-catenin or APC. Science 1997, 275, 1787-1790. [CrossRef]

67. Kinzler, K.W.; Nilbert, M.C.; Su, L.K.; Vogelstein, B.; Bryan, T.M.; Levy, D.B.; Smith, K.J.; Preisinger, A.C.; Hedge, P.; Mckechnie, D.; et al. Identification of FAP locus genes from chromosome 5q21. Science 1991, 253, 661-665. [CrossRef]

68. Romagnolo, D.F.; Zempleni, J.; Selmin, O.I. Nuclear receptors and epigenetic regulation: Opportunities for nutritional targeting and disease prevention. Adv. Nutr. 2014, 5, 373-385. [CrossRef]

69. Wang, H.; Liu, A.; Kuo, Y.; Chi, E.; Yang, X.; Zhang, L.; Yang, C.S. Obesity promotes PhIP-induced small intestinal carcinogenesis in $\mathrm{hCYP} 1 \mathrm{~A}-\mathrm{db} / \mathrm{db}$ mice: Involvement of mutations and DNA hypermethylation of Apc. Carcinogenesis 2016, 37, 723-730. [CrossRef]

70. Li, R.; Grimm, S.A.; Chrysovergis, K.; Kosak, J.; Wang, X.; Du, Y.; Burkholder, A.; Janardhan, K.; Mav, D.; Shah, R.; et al. Obesity, rather than diet, drives epigenomic alterations in colonic epithelium resembling cancer progression. Cell Metab. 2014, 19, 702-711. [CrossRef]

71. Esteller, M.; Sparks, A.; Toyota, M.; Sanchez-Cespedes, M.; Capella, G.; Peinado, M.A.; Gonzalez, S.; Tarafa, G.; Sidransky, D.; Meltzer, S.J.; et al. Analysis of adenomatous polyposis coli promoter hypermethylation in human cancer. Cancer Res. 2000, 60, 4366-4371.

72. Lao, V.V.; Grady, W.M. Epigenetics and colorectal cancer. Nat. Rev. Gastroenterol. Hepatol. 2011, 8, 686-700. [CrossRef]

73. Wang, Z.K.; Liu, J.; Liu, C.; Wang, F.Y.; Chen, C.Y.; Zhang, X.H. Hypermethylation of adenomatous polyposis coli gene promoter is associated with novel Wnt signaling pathway in gastric adenomas. J. Gastroenterol. Hepatol. 2012, 27, 1629-1634. [CrossRef] [PubMed]

74. Deng, G.; Song, G.A.; Pong, E.; Sleisenger, M.; Kim, Y.S. Promoter methylation inhibits APC gene expression by causing changes in chromatin conformation and interfering with the binding of transcription factor CCAAT-binding factor. Cancer Res. 2004, 64, 2692-2698. [CrossRef] [PubMed]

75. Li, B.Q.; Liu, P.P.; Zhang, C.H. Correlation between the methylation of APC gene promoter and colon cancer. Oncol. Lett. 2017, 14, 2315-2319. [CrossRef] [PubMed]

76. Mai, V.; Colbert, L.H.; Perkins, S.N.; Schatzkin, A.; Hursting, S.D. Intestinal microbiota: A potential diet-responsive prevention target in ApcMin mice. Mol. Carcinog. 2007, 46, 42-48. [CrossRef] [PubMed]

(C) 2019 by the authors. Licensee MDPI, Basel, Switzerland. This article is an open access article distributed under the terms and conditions of the Creative Commons Attribution (CC BY) license (http:/ / creativecommons.org/licenses/by/4.0/). 